\title{
Adsorption of Biocellulose Nanofiber Tissue Engineering from Acetobacter Xylinum (Acetobacteraceae) Embedded Eggshell Membrane via Fermentation Process
}

\author{
Nussara Soontorntepwarakul ${ }^{1}$, Neeranuch Wangrungroj ${ }^{1} \&$ Nuchnapa Tangboriboon ${ }^{1}$ \\ ${ }^{1}$ Materials Engineering Department, Faculty of Engineering, Kasetsart University, Bangkok 10900, Thailand \\ Correspondence: Nuchnapa Tangboriboon, Materials Engineering Department, Faculty of Engineering, Kasetsart \\ University, Bangkok 10900, Thailand. E-mail: fengnnpt@ku.ac.th
}

Received: August 6, 2019

doi:10.5539/mas.v13n10p11
Accepted: September 5, $2019 \quad$ Online Published: September 10, 2019

URL: https://doi.org/10.5539/mas.v13n10p11

\begin{abstract}
Interest in the development of bio-based waste has increased exponentially in biomedical, biodental and bioengineering applications because such waste is nontoxic, biocompatible, easily formed, and has good physicochemical-mechanical-thermal properties, elasticity, high purity, no side effects and biodegradation. Eggshell membrane is a biopolymer network of protein fibers retaining albumin, collagen and amino acid. Eggshell membrane is a good food source for bacterial Acetobacter xylinum growth to make a strong biocellulose nanofiber composite for use in facial masks and tissue engineering. The current study added different amounts of eggshell membrane powder of $0 \%$ (Bio-0), 0.01\% (Bio-01), 0.05\% (Bio-05), 0.075\% (Bio-075) and 0.10\%wt (Bio-1) into biocellulose made from Acetobacter xylinum in coconut water medium via a fermentation process. The obtained facial mask encoded Bio-1 had good physicochemical and mechanical properties. The best sample has tensile strength, elongation at break and maximum force, and good adsorption encoded Bio-1 equal to $3.229 \pm 0.297 \mathrm{MPa}, 43.350 \pm 8.400 \% 13.466 \pm 1.238 \mathrm{~N}$, respectively.
\end{abstract}

Keywords: Eggshell membrane, Coconut agar, Biocellulose, Collagen, Tissue engineering, Nanofiber

\section{Introduction}

Currently, many researchers are paying attention to the use of biomaterials, nontoxic materials, and recycled materials such as biological wastes, bio-fiber, industrial wastes and biodegradable materials as a starting material in their work. The promotion of environmental consciousness in industrial applications is becoming more prevalent. Sustainable development and eco-efficiency are now considered to be major responsibilities in every country. In addition, green biomedical products should be of high quality, biocompatible and cheap to produce.

Eggs from hens, ducks and birds have been used as a source of food, drugs, cosmetics and foodstuffs. Eggshells are the egg product residue obtained from the production of eggs and egg derivatives and this waste contributes to environmental pollution as it supports microbial actions. The amount of eggshell waste from the food processing industry in Thailand has increased gradually up to millions of tonnes daily (Tsai et al., 2006). As a by-product, eggshell represents about $11-15 \%$ of the total weight or approximately $60-75 \mathrm{~g}$ per egg and is composed of eggshell (including calcium carbonate $\left(\mathrm{CaCO}_{3}\right)$, magnesium carbonate $\left(\mathrm{MgCO}_{3}\right)$ and other oxide compounds) and eggshell membrane (including many kinds of fibrous proteins such as collagen, hexosamines, glycosaminoglycans, hyaluronic acid and sialic acid) (Tangboriboon et al., 2016). The eggshell membrane is located between the egg white (albumin) and the inner surface of the eggshell. There are two shell membranes around an egg, with a combined total thickness of approximately $100 \mu \mathrm{m}$ which function as a semi-permeable membrane to prevent the penetration of bacteria (Tsai et al.,2006 \& Torres et al., 2010). Eggshell membrane is a potential alternative, important biomaterial source of collagen for application in supplementary foods, cosmetics, drugs, and healthcare and biomedical products such as in wound healing bandages, hydrogel, foams, biofilms and facial masks (Mogoşanu \& Grumezescu, 2014). The advantages of eggshell membrane have made it of interest as a biomaterial in biomedical engineering due to its biocompatibility and biodegradability for cell culture, skin and vascular grafts (Yi et al., 2004).

Nowadays, various kinds of tissue engineering and facial masks are applied for different purposes such as revitalizing, healing, refreshing and long-term benefits to body and facial skins. Facial masks and tissue 
engineering can be made from various sources. Cellulose masks are obtained from natural sources such as plant product, algae, fungi and bacteria, especially the Acetobacter xylinum bacterium which is of interest because of its non-pathogenic, non-spore forming, non-toxic and biodegradable properties. A. xylinum in coconut water medium can form acetic acid and a white layer that floats above the liquid medium called Nata de Coco, which is jelly-like due to fermentation. Coconut water contains a large amount of sugar and nitrogen-containing compounds (Verschuren et al., 1999). In addition, bacteria cellulose can be made from sugar cane and other fruit juices such as pineapple, melon, grape, apple, pear, guava and banana peel (Upadhyay et al., 2010). Cellulose is an organic polysaccharide consisting of a linear chain of several hundred to over ten thousand $\beta(1 \rightarrow 4)$ linked D-glucose units and is widely used to make paper and textile masks (Aramwit \& Bang, 2014). The advantages of biocellulose made from A. xylinum are excellent physical, mechanical and thermal properties, purity and biocompatibility for bone tissue scaffolds, artificial blood vessels, artificial skin and dental implants (Jang et al., 2017). The tensile strength of a single biocellulose fiber is almost comparable to $\mathrm{Kevlar}^{\circledR}$ and steel, so that such fibers can be a suitable candidate where high mechanical performance is required (Yano et al, 2005 \& Czaja et al, 2006). Furthermore, the competitive advantages and applications of biocellulose $A$. xylinum have been applied in food industries, cosmetics, electronic industries, wound dressing, acoustic diaphragms of speakers and headphones, batteries and organic light emitting diodes (Barud et al, 2011; Cacicedo et al., 2016; Dobre et al., 2012; Ullah et al, 2016; Iguchi et al, 2000; Jiang et al, 2015; Legnani et al, 2008; and Hu et al, 2014).

Biocellulose based on nanocomposites has been developed for biomedical and pharmaceutical applications (Hu et al, 2014; Butchosa et al, 2013; UI-Isalam M et al, 2013; Grande et al, 2009; and Hasan et al, 2012). Therefore, the objective of this study was to prepare a nanofiber composite of eggshell membrane and biocellulose made from A. xylinum bacterium in a coconut water medium via fermentation. The physical and mechanical properties of the facial masks or tissue engineering made using the biocellulose nanocomposite were compared with a bio-commercial facial mask made using biomaterial.

\section{Experimental}

\subsection{Materials}

Eggshell with adhered eggshell membrane was supplied from CPF (Thailand) Public Co., Ltd., Nakhon Nayok province, Thailand. Raw eggshell waste was separated using an eggshell classifier. Eggshell membrane was from eggshell particles. Coconut water was obtained from a local market, Bangkok, Thailand. Acetobacter xylinum was obtained from the Institute of Food Research and Product Development, Kasetsart University, Bangkok, Thailand.

\subsection{Instruments}

Fourier-transform infrared (FTIR) spectra were determined using a spectrometer (Perkin Elmer, Bruker-Alpha E; Waltham, MA, USA) with a spectral resolution of $4 \mathrm{~cm}^{-1}$ in the range $500-4000 \mathrm{~cm}^{-1}$. The samples were prepared using a single-crystal of potassium bromide $(\mathrm{KBr})$ for raw material characterization.

Scanning electron microscope (SEM) micrographs and SEM nanofibers were characterized using a scanning electron microscope (JEOL-JSM-6400; Tokyo, Japan). The microstructures of the eggshell membrane (before and after grinding), a bio-commercial facial mask and the biocellulose tissue engineering or facial mask prepared in the current study were mounted onto stubs using a carbon paste and were sputter-coated to $\sim 0.1 \mu \mathrm{m}$ with gold to improve electrical conductivity. The acceleration voltage was $20 \mathrm{kV}$ with magnifications of $50,10,000$ and 20,000 times.

Contact angle was measured using a contact angle meter (Kyowa, DM-CE 1; Tokyo, Japan). Separate droplets (using a water base) of vitamin $\mathrm{C}$, vitamin $\mathrm{E}$ and oil were deposited onto different positions on the sample surfaces (bio-commercial facial mask and bio-cellulose tissue engineering or facial mask). The images were captured continuously at an interval consistent with the theory as shown in Figure S1. 


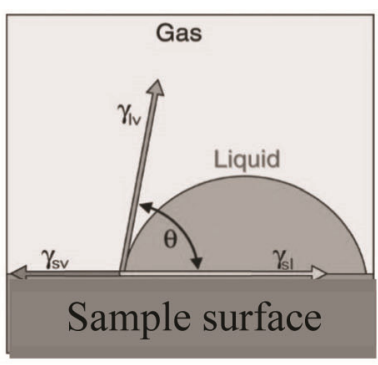

a)

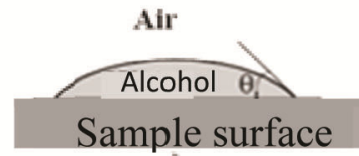

b)

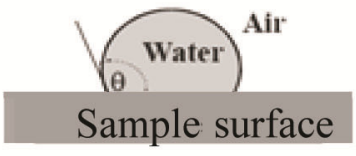

c)

Figure S1. Junction of interfacial tension of a liquid droplet on: a) Interfacial tension of solid surface; b) high wetting with small contact angle of liquid droplet on solid surface, and c) low wetting with large contact angle of liquid droplet on solid surface.

Mechanical properties (tensile strength, stiffness, elongation at break and maximum load) of bio-commercial and bio-cellulose tissue engineering or facial masks were measured using a Universal Testing Machine (UTM, H50KS; Hounsfield, UK). The samples were prepared according to ASTM D 412 as shown in Figure S2 and measured the mechanical properties according to the TIS 1056-2540.

Near infrared (NIR) spectroscopy (Bran + Luebbe, Infra Alyzer 500, Norderstedt, Germany) was used to study the NIR spectra of the bio-commercial and biocellulose facial masks in the of 1,100-2,500 nm or as wave number in the range $12,500-4,000 \mathrm{~cm}^{-1}$.

\subsection{Biocellulose Nanocomposite Tissue Engineering or Facial Mask Preparation}

Eggshell membrane was classified using the eggshell classifier and ground to fine powder using a rapid ball mill for $1 \mathrm{hr}$. The eggshell membrane powder had an average particle size of $64.23 \mu \mathrm{m}$ (Figure S3). The eggshell membrane powder was cleaned using hydrogen peroxide $\left(\mathrm{H}_{2} \mathrm{O}_{2}\right)$ and water to eliminate impurities. Then, the eggshell powder was dried at $40^{\circ} \mathrm{C}$ for $20 \mathrm{~min}$. The growth of $A$. xylinum was prepared using coconut water mixed with acetic acid, sugar and ammonium sulfate (Figure S4). The mixture solution was added with eggshell membrane powder at $0 \%$ (Bio-0), 0.01\% (Bio-01), 0.05\% (Bio-05), 0.075\% (Bio-075) and 0.10\%wt (Bio-1) and then the $\mathrm{pH}$ was adjusted using acetic acid to 3.5-4.0 before pouring into separate Petri dishes. The formation of biocellulose tissue engineering or facial masks was allowed for 5 days via fermentation (Figure S5). Functional theory suggests that the facial masks provide slow release drug delivery via diffusion and adsorption of liquid between the cell culture and the facial mask surface, as shown in Figure S5. The contact angles of liquid droplets (oil, vitamin $\mathrm{C}$ and vitamin $\mathrm{E}$ ) on the bio-commercial and biocellulose tissue engineering or facial mask surfaces were measured at the $1^{\text {st }}$ minute when the liquid droplet started to fall on the bio-commercial facial mask surface and at the $7^{\text {th }}$ minute when the liquid droplet was spreading on the bio-commercial facial mask surfaces.

ASTM D412 TYPE A, B, C, D, E, F
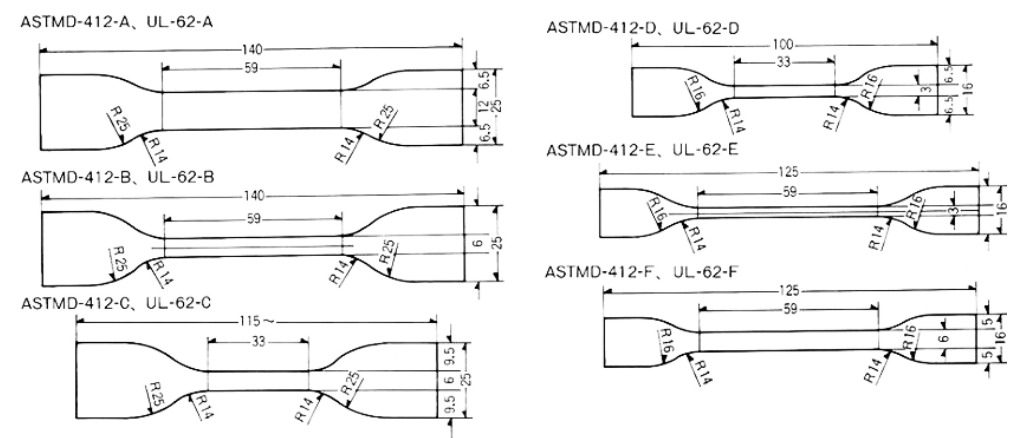

Figure S2. Sample preparation for mechanical property testing (units shown in millimeters) according to ASTM D412. 


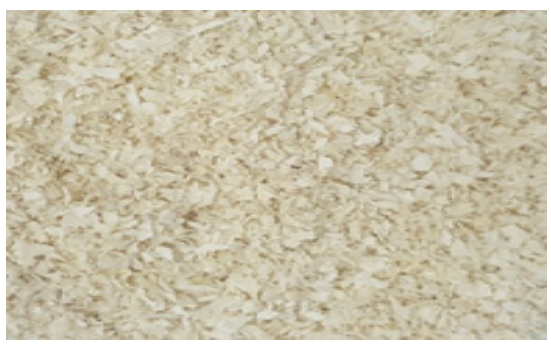

a)

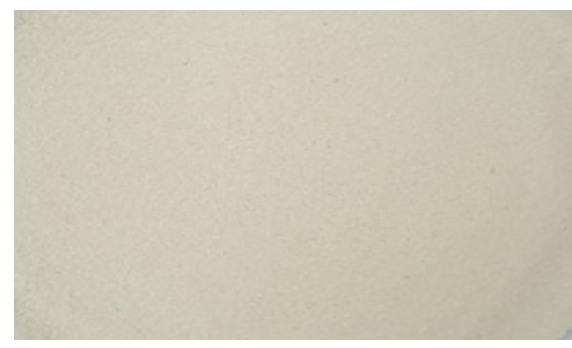

b)

Figure S3. Eggshell membrane preparation cleaned with tap water and hydrogen peroxide and allowed to dry 1-2 days: a) before grinding and b) after grinding with the rapid ball mill.
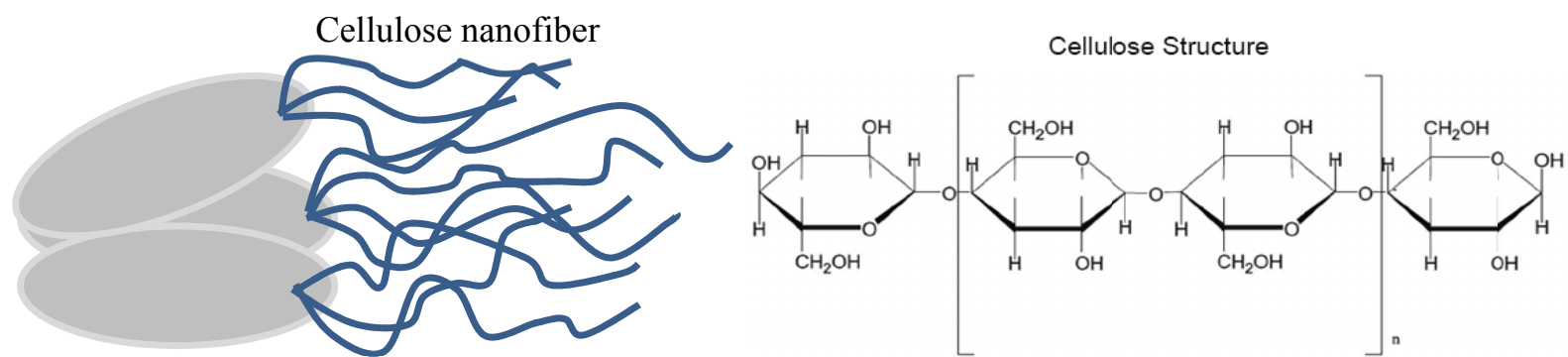

\section{Acetobacter xylinum}

Figure S4. Growth of Acetabacter xylinum in coconut water medium composed of glucose and nitrogen content to form cellulose nanofiber.

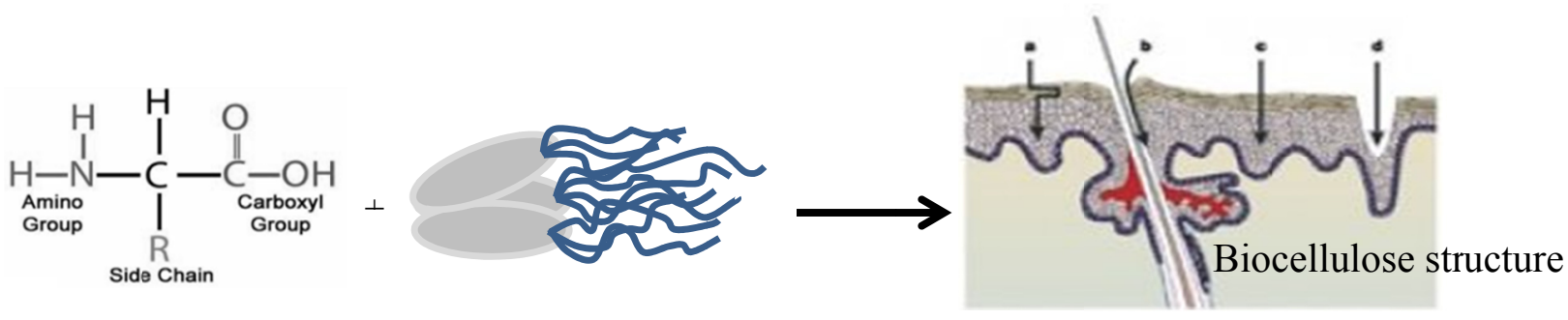

Amino acid in eggshell membrane powder

Acetobacter xylinum
Biocellulose tissue engineering nanocomposite

Figure S5. Drug delivery, tissue engineering or facial mask formation.

\section{Results and Discussion}

\subsection{Physical and Chemical Properties of Biocellulose Tissue Engineering or Facial Masks}

The chemical composition of eggshell membrane was collagen $35 \%$, glucosamine $10 \%$, chondroitin $9.0 \%$, hyaluoric acid about $10 \%$ and other proteins $36 \%$ as shown in Table 1 . The obtained chemical composition results are consistent with the results reported by Ruff KJ et al, 2018. They reported all healthy postmenopausal women (40-75 years of age), who had problems with a joint or connective tissue disorder on ankles, knees, or hips. After eating $500 \mathrm{mg}$ daily of eggshell membrane, they can improve recovery from exercise-induced joint pain ( 8 days) and stiffness (4 days) and also significantly reduced the discomfort from stiffness immediately following exercise (7 days) (Ruff et al., 2018). (King'ori AM, 2011) reported applications of eggshell membrane for skin, cosmetic and food industries as thickener, emulsifier and filler. Collagen, glucosamine, chondroitin and hyaluoric acid in eggshell can rebuild damaged joint without surgery. Collagen can be used for cosmetic and 
burns surgery (King'ori, 2011 \& Matsuda et al, 2006). Furthermore, the particular application of collagen became possible to restore cosmetic appeal of fire victims. It is an alternative way for their lives the rest of their lives with the absolute disfigurement a fire accident. It can substitute to construct the artificial skin for skin burn position (King'ori, 2011 \& Matsuda et al, 2006).

Table 1. Chemical composition of eggshell membrane

\begin{tabular}{ll}
\hline Composition & $\begin{array}{l}\text { Amount of chemical composition } \\
\text { (average \% by weight) }\end{array}$ \\
\hline Collagen (I, V, X) & 35.0 \\
Glucosamine & 10.0 \\
Chondroitin & 9.0 \\
Hyaluoric acid & $5.0-10.0$ \\
Other proteins & 36.0
\end{tabular}

Three different commercial facial masks (bio-cellulose commercial, cotton and paper sheet) were used as reference samples to compare physical, chemical and mechanical properties with the obtained biocellulose tissue engineering or facial masks. The thickness and amount of water absorption were measured and are shown in Table 2. The average thickness for the biocellulose tissue engineering or facial masks made in the current study were $0.252-0.287 \pm 0.001 \mathrm{~mm}$. The water absorption efficiency of biocellulose tissue engineering or facial masks (both commercial and made in the current study) was more than $70 \%$, with the highest value (96.799 \pm $1.000 \%)$ being for the sample encoded Bio-1 (0.100\% eggshell membrane powder adding).

Table 2. Thickness values of tissue engineering or facial masks

\begin{tabular}{|c|c|c|}
\hline Sample & $\begin{array}{l}\text { Thickness } \\
\text { (avg. } \pm \text { SD) } \\
(\mathrm{mm})\end{array}$ & $\begin{array}{l}\text { Water absorption } \\
(\text { avg } \pm \mathrm{SD}) \\
\%\end{array}$ \\
\hline $\begin{array}{l}\text { Biocellulose-commercial masks } \\
\text { (Bio-commercial) }\end{array}$ & $0.056 \pm 0.001$ & $>96.000$ \\
\hline $\begin{array}{l}\text { Cotton commercial masks } \\
\text { (Cot-commercial) }\end{array}$ & $0.594 \pm 0.001$ & $>96.000$ \\
\hline $\begin{array}{l}\text { Paper sheet commercial masks } \\
\text { (Sheet-commercial) }\end{array}$ & $0.483 \pm 0.001$ & $>96.000$ \\
\hline $\begin{array}{l}0.000 \% \text { added eggshell membrane } \\
\text { (Bio- } 0)\end{array}$ & $0.289 \pm 0.001$ & $88.820 \pm 1.000$ \\
\hline $\begin{array}{l}0.010 \% \text { added eggshell membrane } \\
\text { (Bio-01) }\end{array}$ & $0.252 \pm 0.001$ & $71.814 \pm 1.000$ \\
\hline $\begin{array}{l}0.050 \% \text { added eggshell membrane } \\
\text { (Bio-05) }\end{array}$ & $0.277 \pm 0.001$ & $91.290 \pm 1.000$ \\
\hline $\begin{array}{l}0.075 \% \text { added eggshell membrane } \\
\text { (Bio-075) }\end{array}$ & $0.287 \pm 0.001$ & $89.488 \pm 1.000$ \\
\hline $\begin{array}{l}0.100 \% \text { added eggshell membrane } \\
\text { (Bio-1) }\end{array}$ & $0.274 \pm 0.001$ & $96.799 \pm 1.000$ \\
\hline
\end{tabular}

The SEM micrographs for the eggshell membrane (before and after grinding) are shown in Figure 1. The eggshell membrane before grinding showed collagen nanofibers and proteins containing many kinds of amino acid and other nutrients as food consistent with the chemical composition of eggshell membrane in Table1 useful for the growth rate of A. xylinum. Furthermore, following grinding there was increased specific surface area for good fermentation (Figure 1).

The contact angles of liquid droplets (oil, vitamin C and vitamin E) on the surfaces of the bio-commercial and biocellulose tissue engineering or facial mask made in the current study are shown in Figure 2 and Figure 3, 
respectively. Most of the liquid droplets on biocellulose facial mask surfaces had smaller contact angle than those of bio-commercial facial mask surfaces which indicated that the biocellulose tissue engineering or facial masks were of good quality for liquid adsorption due to high wetting ability.
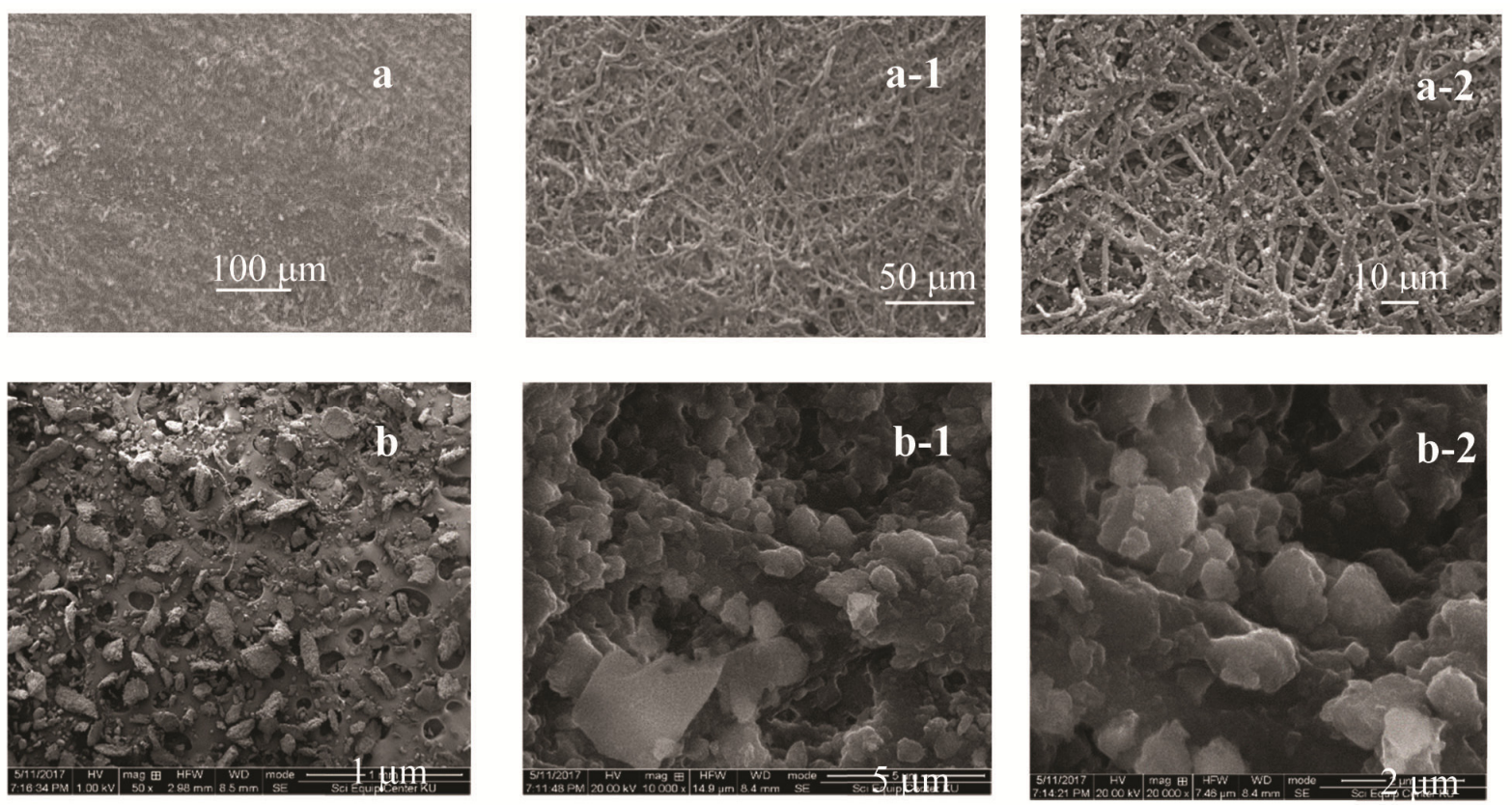

Figure 1. SEM micrographs and nanofibers of eggshell membrane before and after grinding: a) 200X before grinding; a-1) 500X before grinding; a-2) 1,000X before grinding and b) 50X after grinding; b-1) 10,000X after grinding; b-2) 20,000X after grinding.
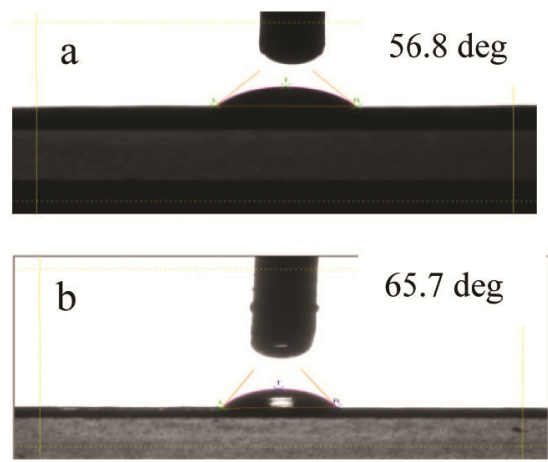

c
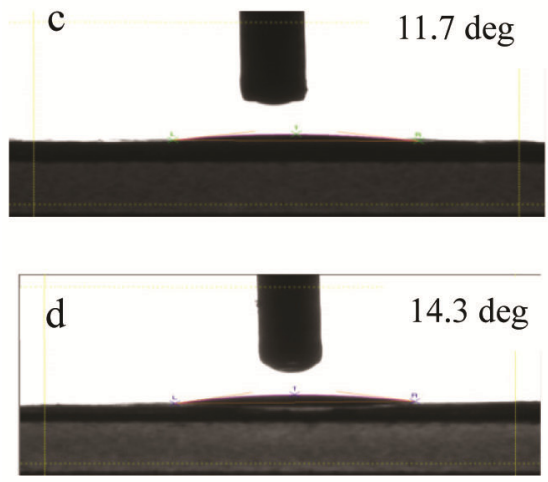
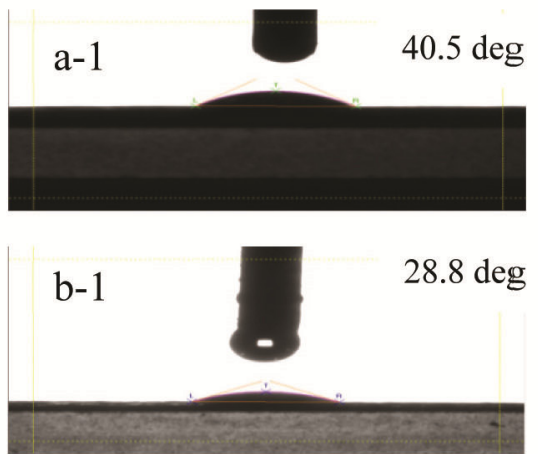

c-1

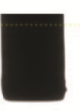

$2.6 \mathrm{deg}$
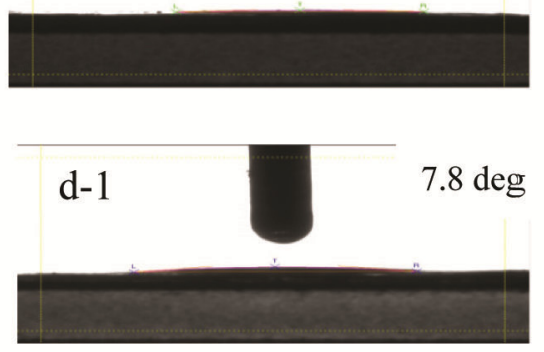

Figure 2. Contact angle of liquid droplet absorption on bio-commercial facial masks: a and a-1) oil; b and b-1) vitamin $\mathrm{E}$; $\mathrm{c}$ and $\mathrm{c}-1$ ) vitamin $\mathrm{C}$; $\mathrm{d}$ and $\mathrm{d}-1$ ) water. 
Nanostructure fiber comparisons of the facial masks are shown in Figure 4. The SEM nanostructure fiber of the commercial facial mask showed a dense, networked fiber structure, while the biocellulose tissue engineering or facial mask sample without added eggshell (Bio-0) in the membrane powder showed and opaque nanostructure and a small amount of fiber network (Figures 4b, 4b-1 and 4b-2). In addition, the SEM nanostructures of biocellulose tissue engineering or facial mask sample with added eggshell (Bio-1) in the membrane powder showed a porous, networked fiber structure due to the fermentation of A. xylinum with the eggshell membrane to form a nanocomposite facial mask (Figures 4c, 4c-1 and 4c-2). The obtained results were consistent with the SEM results of the A. xylinum growth in other kinds of fruit juice (orange, grape, apple, jackfruit and guava) (Li et al, 2015; Tomita \& Kondo, 2009; Ummartyotin \& Pechyen, 2016; and Fu et al, 2013). The characteristic of high porosity, networked fiber structures of biocellulose-eggshell membrane tissue engineering or facial masks are advantageous to rapid adsorption of a high amount of liquid such as vitamin C, vitamin E and oil.
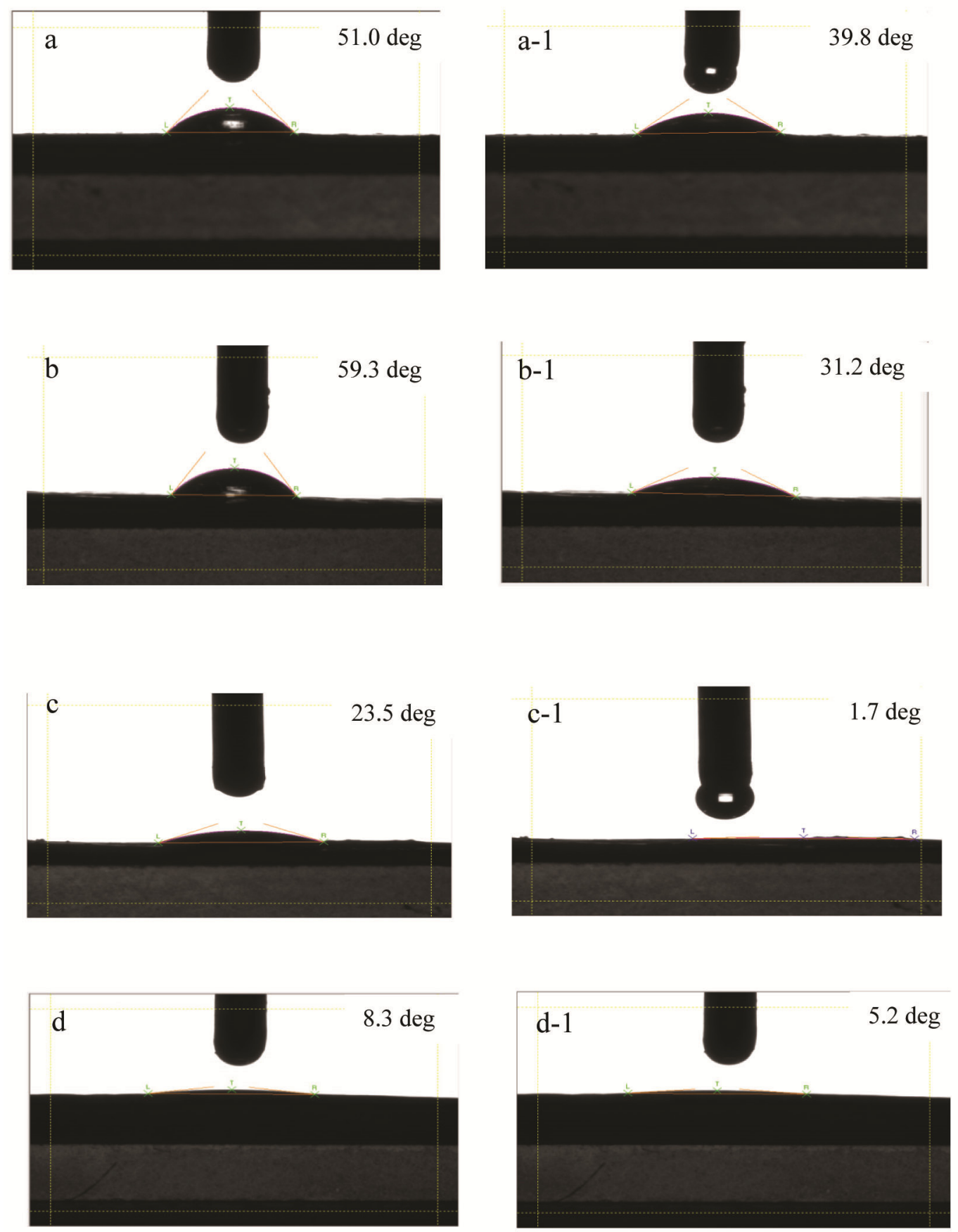

Figure 3. Contact angle of liquid droplet absorption on the biocellulose-eggshell membrane tissue engineering or facial masks (Bio-1): a and a-1) oil; b and b-1) vitamin E; c and c-1) vitamin C; d and d-1) water. 


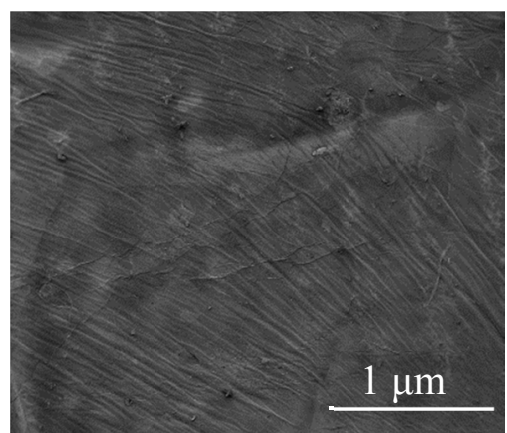

a)

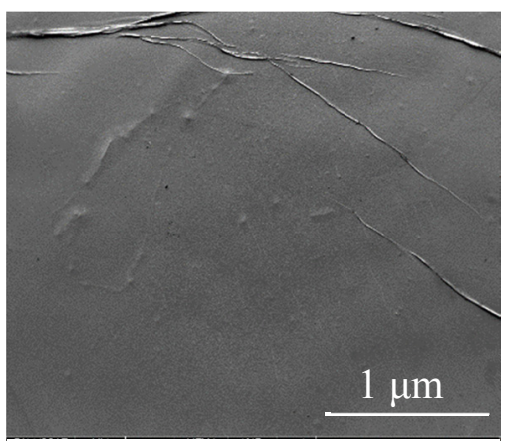

b)

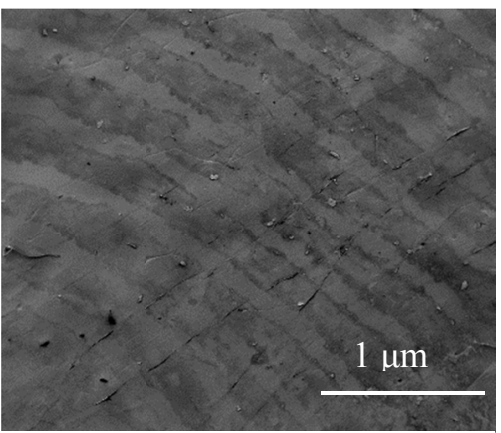

c)

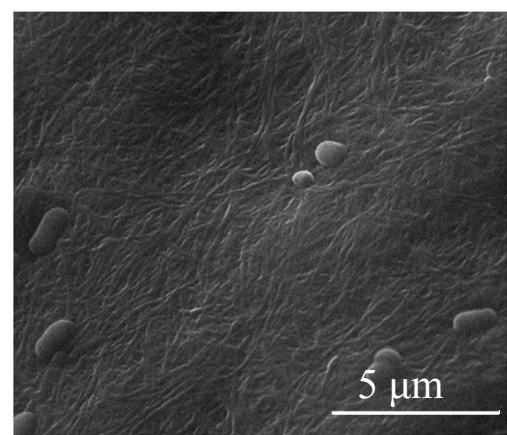

a-1)

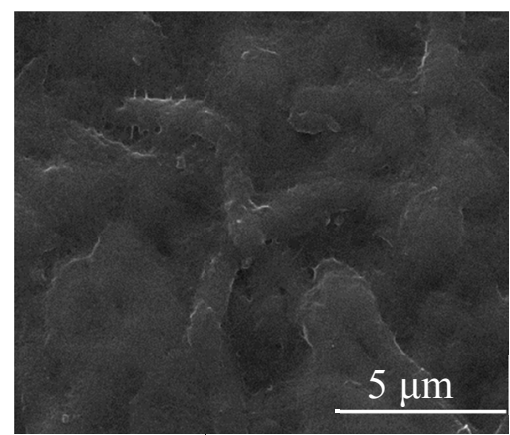

b-1)

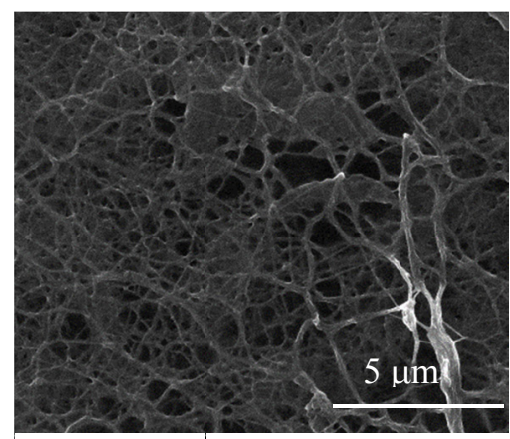

c-1)

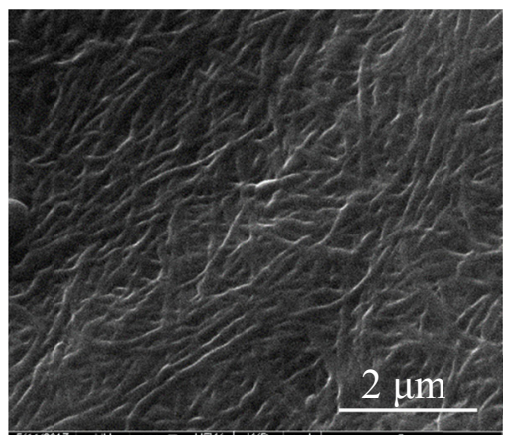

a-2)

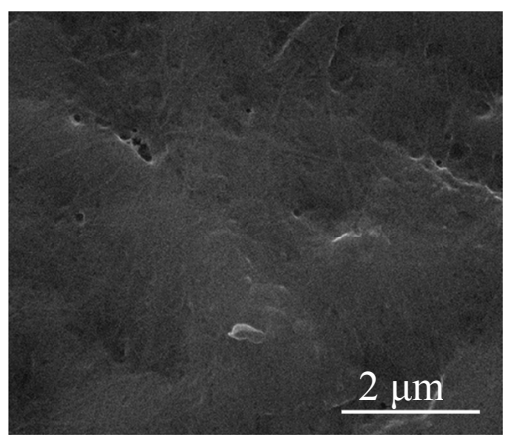

b-2)

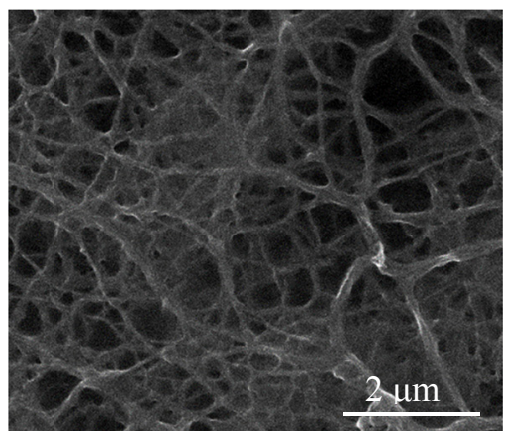

c-2)

Figure 4. Microstructure and nanostructure comparison of tissue engineering or facial masks with magnifications of 50X; 10,000X; 20,000X, respectively of: a, a-1 and a-2) bio-commercial facial masks; b, b-1 and b-2 biocellulose without added eggshell membrane in tissue engineering or facial masks and c, c-1 and c-2) biocellulose-eggshell membrane tissue engineering or facial masks (Bio-1).

The fiber diameter distribution versus the amount of fiber in bio-commercial and biocellulose tissue engineering or facial mask was measured using SEM and the statistical calculations of the results are shown in Figure 5. The fiber diameter distribution of the biocellulose tissue engineering or facial mask (Bio-1; Figure 5b) had greater amounts of smaller fibers than that of the bio-commercial facial mask (Figure 5a). This is an important factor in determining the mechanical properties of the tissue engineering and facial mask.

The FTIR spectra of raw materials (eggshell membrane powder, vitamin C, vitamin $\mathrm{E}$ and oil), the bio-commercial facial mask and the Bio-1 tissue engineering or facial mask were measured in the range of wave number $500-4000 \mathrm{~cm}^{-1}$ as shown in Figure 6. FTIR spectra indicated that the eggshell membrane powder was composed of $\mathrm{Ca}-\mathrm{O}$ at wave numbers $500-600 \mathrm{~cm}^{-1}$ and $\delta(=\mathrm{CH})$ at $875 \mathrm{~cm}^{-1}$. There were functional groups of $v(\mathrm{P}=\mathrm{O}), \mathrm{v}(\mathrm{C}=\mathrm{S}), \mathrm{v}(\mathrm{C}-\mathrm{O}), \mathrm{v}(\mathrm{S}=\mathrm{O})$ and $\mathrm{v}(\mathrm{C}-\mathrm{N})$ in the range $1000-1500 \mathrm{~cm}^{-1}$. The $v(\mathrm{~N}-\mathrm{H}), \mathrm{v}(\mathrm{N}=\mathrm{O})$ and $\mathrm{v}(\mathrm{C}=\mathrm{C})$ of amino acid belonging to collagen, hyaluoric acid, glucosamine and chondroitin appeared at 1574 and $1650 \mathrm{~cm}^{-1}$. The FTIR spectrum of coconut jelly made from A. xylinum in coconut water without eggshell membrane powder was similar to that of biocellulose tissue engineering with added eggshell membrane (Bio-1) and the bio-commercial facial mask at 1636 and $3341 \mathrm{~cm}^{-1}$ belonging to $v(\mathrm{C}=\mathrm{C})$ and $v(\mathrm{O}-\mathrm{H})$, respectively, which 
indicated hydrogel properties. The FTIR spectra of vitamin $\mathrm{C}$, vitamin $\mathrm{E}$ and oil appeared at the same peaks at $920,1159,1464,1750,2867$ and $2922 \mathrm{~cm}^{-1}$ belonging to $v(=\mathrm{C}-\mathrm{H}), v(\mathrm{C}-\mathrm{O}), v(\mathrm{C}-\mathrm{N}), v(\mathrm{C}=\mathrm{C}), v(\mathrm{C}=\mathrm{N})$ and $v$ $(-\mathrm{C}-\mathrm{H})$, respectively. Furthermore, $v(\mathrm{O}-\mathrm{H})$ of vitamin $\mathrm{C}$ was found in the FTIR spectrum at $3310-3520 \mathrm{~cm}^{-1}$ and the carboxylic group $\delta(\mathrm{COOH})$ at $863-981 \mathrm{~cm}^{-1}$. Peaks for $v(\mathrm{C}=\mathrm{N}), v(\mathrm{P}-\mathrm{O})$ and $v(\mathrm{C}=\mathrm{S})$ at $920-1109 \mathrm{~cm}^{-1}$ appeared in vitamin $\mathrm{E}$. In addition, there was another peak of both vitamin $\mathrm{E}$ and oil at the same position of 1366 $\mathrm{cm}^{-1}$ belonging to $v\left(\mathrm{NO}_{2}\right)$.

The FTIR spectra of the bio-commercial facial mask and the Bio-1 tissue engineering or facial masks with and without oil, vitamin $\mathrm{E}$ and vitamin $\mathrm{C}$ were characterized as shown in Figure 7. The results for the biocellulose tissue engineering or facial masks with oil, vitamin $\mathrm{E}$ and vitamin $\mathrm{C}$ were consistent with the FTIR spectra of purity oil, vitamin $\mathrm{E}$ and vitamin $\mathrm{C}$ as shown in Figure 6.

In the FTIR spectra of both the bio-commercial and Bio-1 tissue engineering or facial masks oil, vitamin $\mathrm{E}$ and vitamin $C$ appeared at the same peak positions (Figure 8), indicating that the obtained Bio-1 tissue engineering or facial masks made from the A. xylinum with eggshell membrane powder have potential for use as commercial facial masks.

a) Commercial facial mask

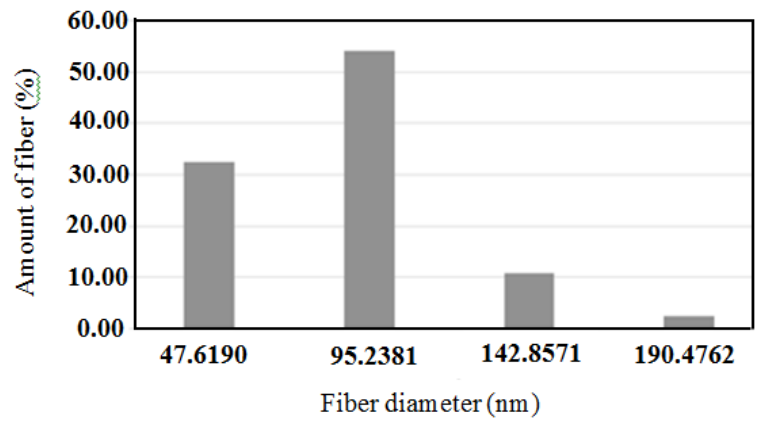

b) Bio-1 tissue engineering

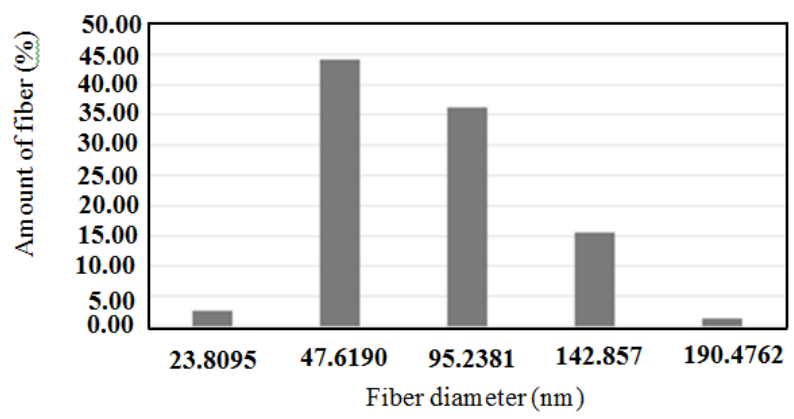

Figure 5. Comparison of fiber percentages between bio-commercial and biocellulose tissue engineering or facial masks (Bio-1).

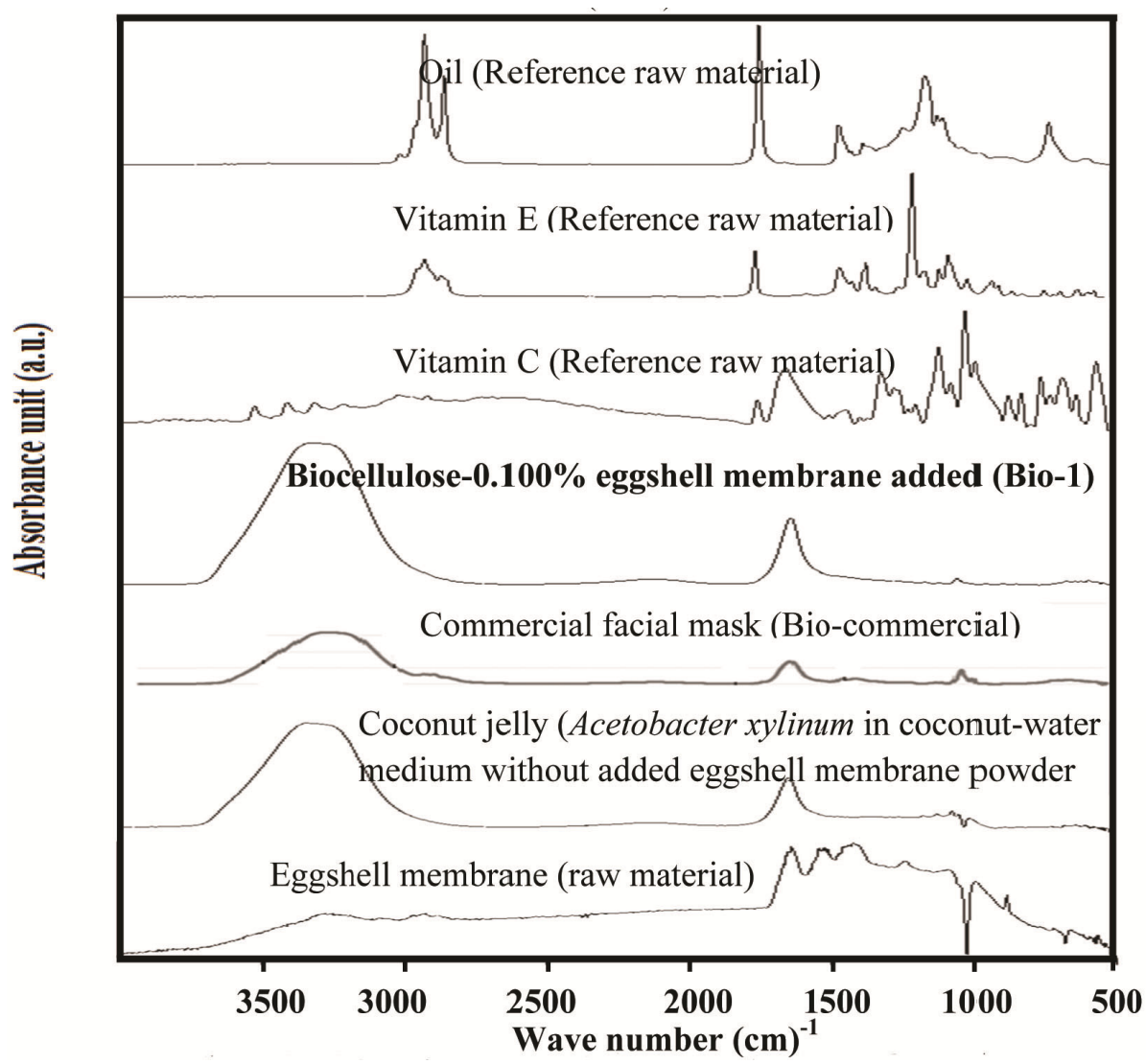

Figure 6. FTIR spectra of raw material, vitamin C, vitamin E and oil. 


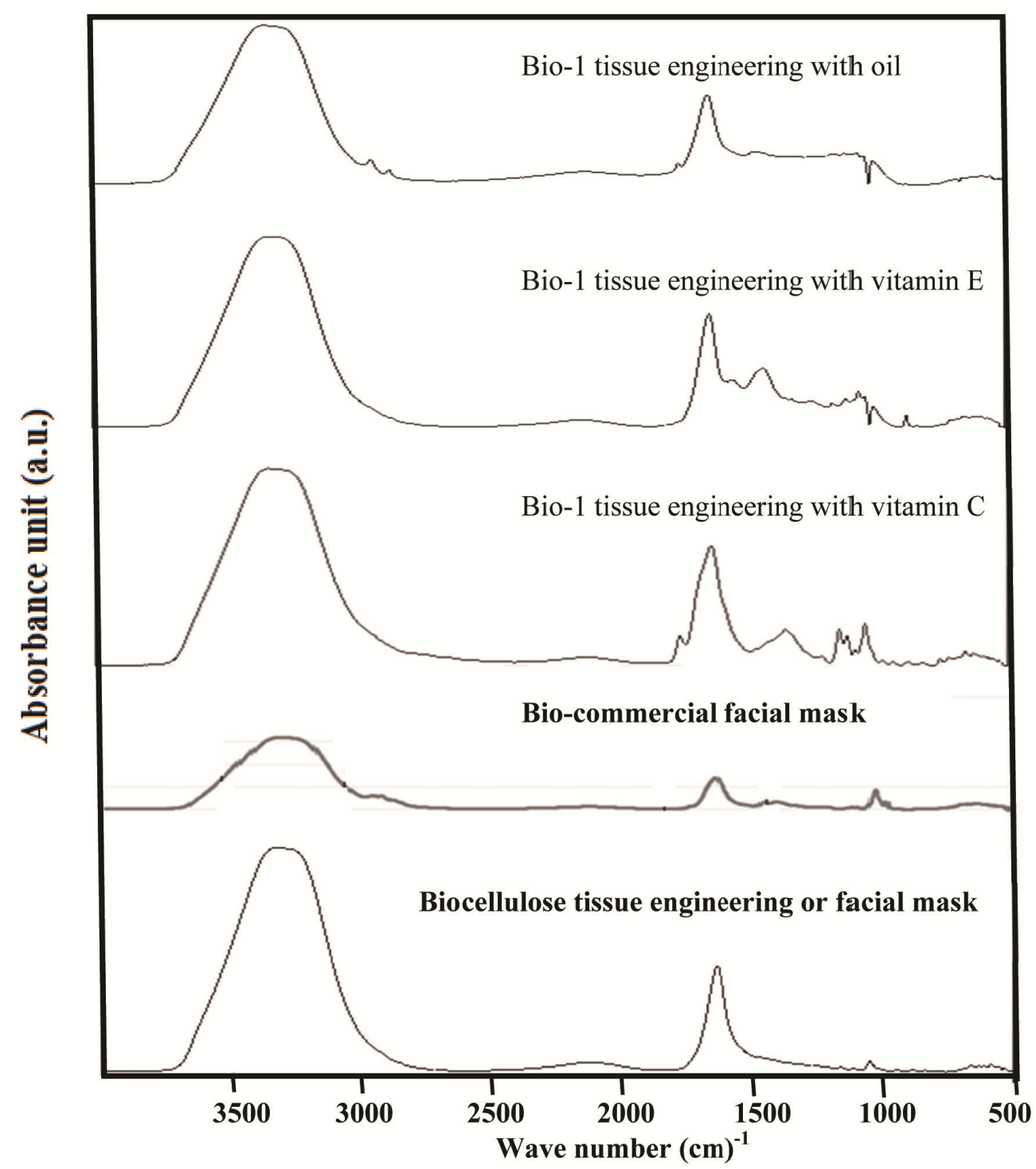

Figure 7. FTIR spectra of bio-commercial and Bio-1 tissue engineering or facial masks with/without absorption vitamin $\mathrm{C}$, vitamin $\mathrm{E}$ and oil.

The NIR spectra of eggshell membrane powder and Bio-1 showed the same peak positions belonging to amino acid, collagen, hyaluoric acid, glucosamine and chondroitin suitable for preparation cellulose masks from Acetobacter xylinum bacterium via fermentation process as shown in Figure 9.

\subsection{Mechanical Properties of Biocellulose Tissue Engineering or Facial Masks}

The mechanical properties (tensile strength, elongation at break and maximum force) of the biocommercial facial mask and biocellulose tissue engineering or facial mask with and without eggshell membrane powder are shown in Table 3 and Figure 10. The amount of eggshell membrane powder added into tissue engineering or facial mask increased the tensile strength, elongation at break and maximum force. The best conditions (mean $\pm \mathrm{SD}$ ) occurred in the biocellulose tissue engineering or facial mask (Bio-1) by adding $0.1 \% \mathrm{wt}$ eggshell membrane to obtain good tensile strength $(3.229 \pm 0.297 \mathrm{MPa})$, high elongation at break $(43.350 \pm 8.400 \%)$ and maximum force $(13.466 \pm 1.238 \mathrm{~N})$. The biocommercial facial mask had values for tensile strength, elongation at break and maximum force of $2.469 \pm 0.222 \mathrm{MPa}, 31.104 \pm 8.252 \%$ and $15.857 \pm 9.521 \mathrm{~N}$, respectively. Therefore, the obtained mechanical testing results indicate their potential to produce biocellulose tissue engineering or facial masks due to good mechanical properties and high elasticity. 


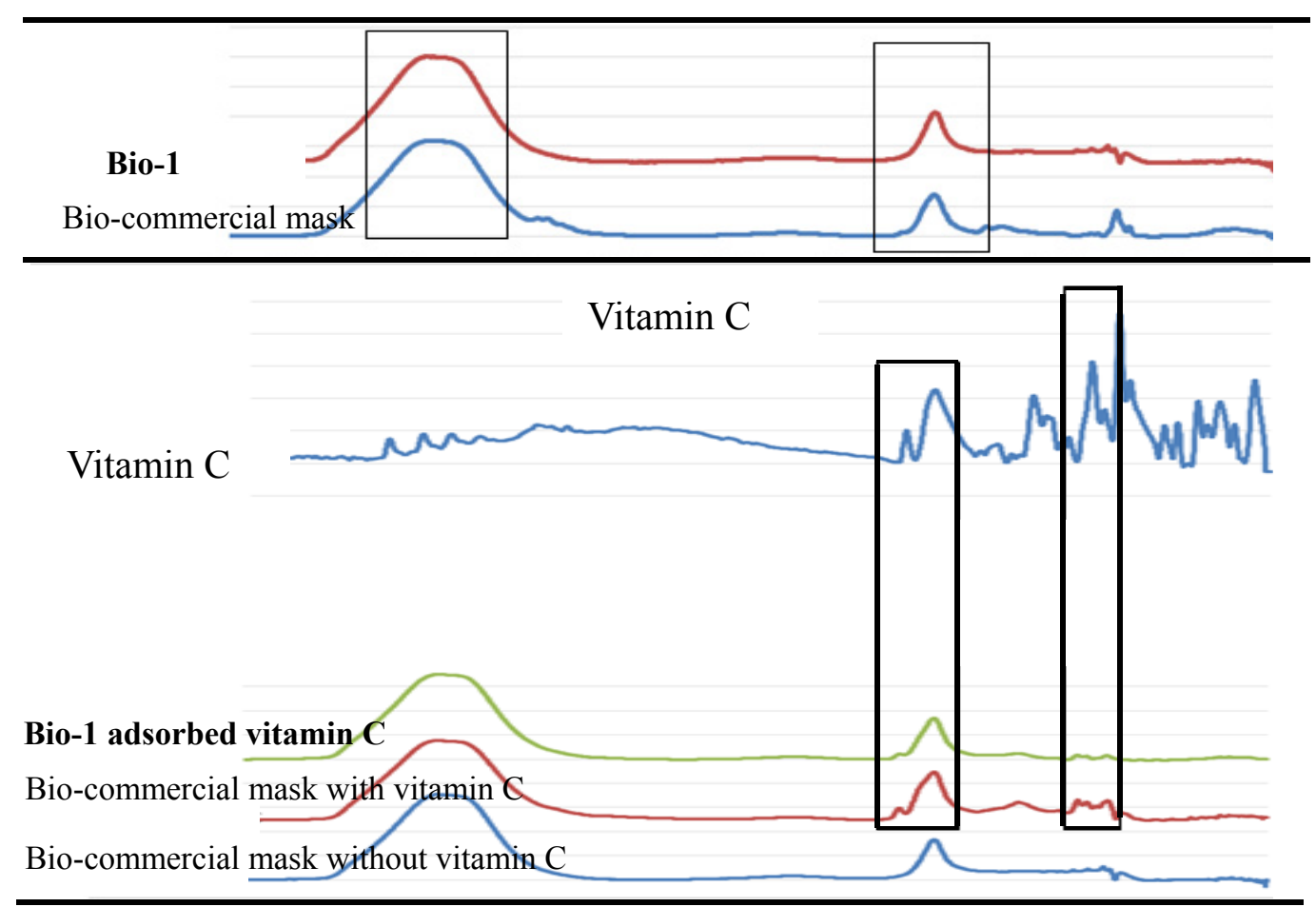

Vitamin E

\section{Bio-1adsorbded vitamin $\mathrm{E}$}

Bio-commercial mask with vitamin $E$

Bio-commercial mask without vitamin E

Oil

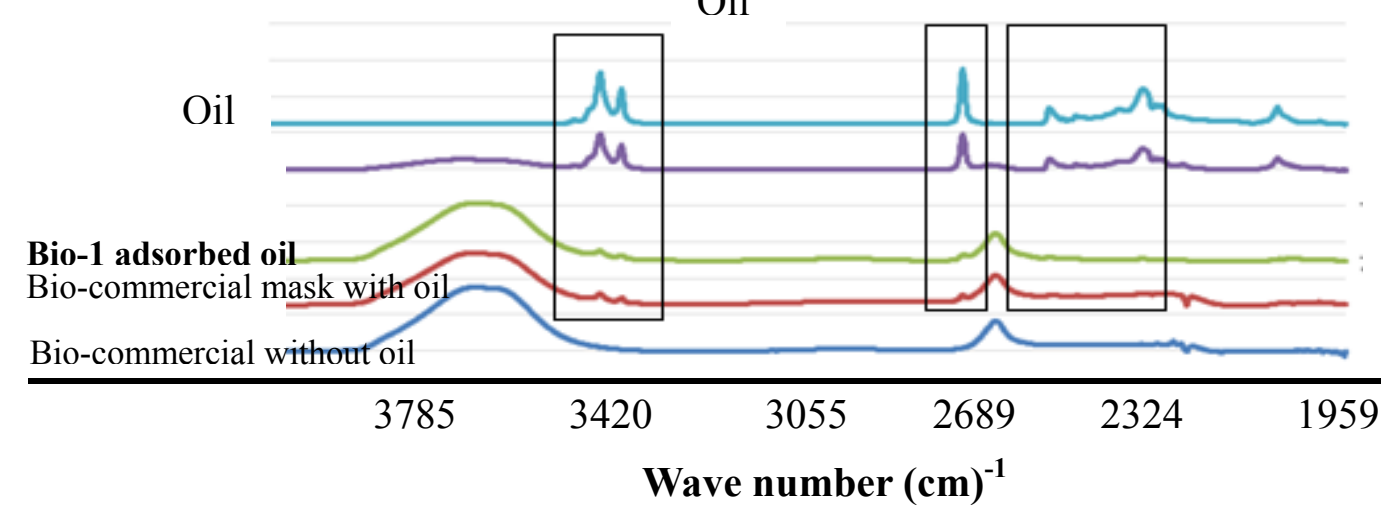

Figure 8. FTIR spectra comparison of chemical functional groups between bio-commercial and biocellulose tissue engineering or facial masks for oil, vitamin $\mathrm{C}$ and vitamin $\mathrm{E}$. 


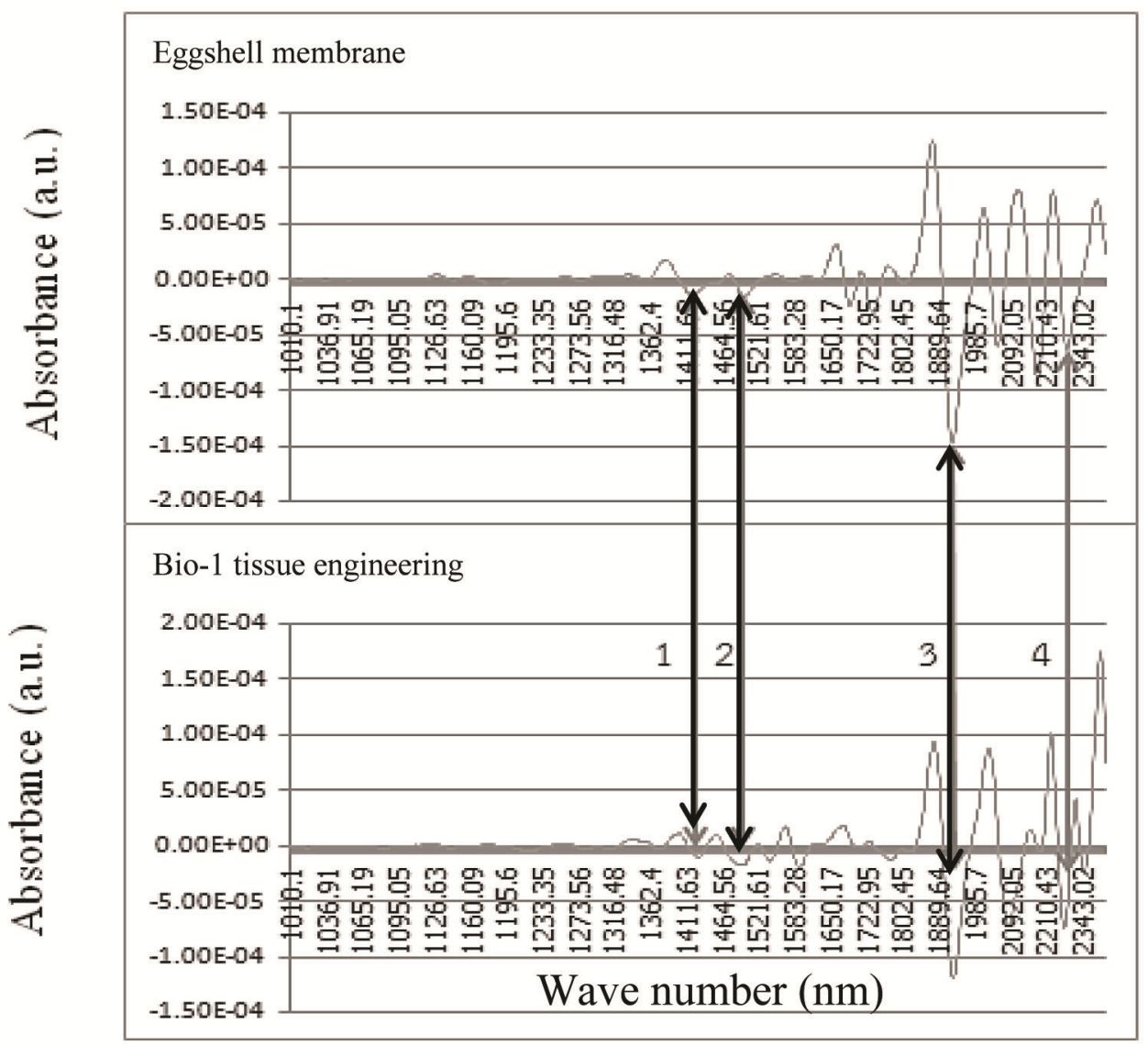

Figure 9. NIR spectra of eggshell membrane and biocellulose tissue engineering or facial mask (Bio-1).

Table 3. Mechanical properties of tissue engineering or facial masks

\begin{tabular}{lccc}
\hline Sample & $\begin{array}{c}\text { Tensile strength } \\
(\text { avg. } \pm \text { SD })\end{array}$ & $\begin{array}{c}\text { Elongation at break } \\
(\text { avg. } \pm \text { SD }) \\
(\%)\end{array}$ & $\begin{array}{c}\text { Max force } \\
\text { (avg. } \pm \text { SD }) \\
(\mathrm{NPa})\end{array}$ \\
\hline Bio-commercial & $2.469 \pm 0.222$ & $31.104 \pm 8.252$ & $15.857 \pm 9.521$ \\
Bio-0 & $0.863 \pm 0.185$ & $12.252 \pm 1.649$ & $3.600 \pm 0.773$ \\
Bio-01 & $1.213 \pm 0.141$ & $25.446 \pm 2.469$ & $5.057 \pm 0.587$ \\
Bio-05 & $0.690 \pm 0.248$ & $20.990 \pm 13.202$ & $2.877 \pm 1.035$ \\
Bio-075 & $1.185 \pm 0.572$ & $28.583 \pm 12.293$ & $4.943 \pm 2.384$ \\
Bio-1 & $\mathbf{3 . 2 2 9} \pm \mathbf{0 . 2 9 7}$ & $\mathbf{4 3 . 3 5 0} \pm \mathbf{8 . 4 0 0}$ & $\mathbf{1 3 . 4 6 6} \pm \mathbf{1 . 2 3 8}$ \\
\hline
\end{tabular}




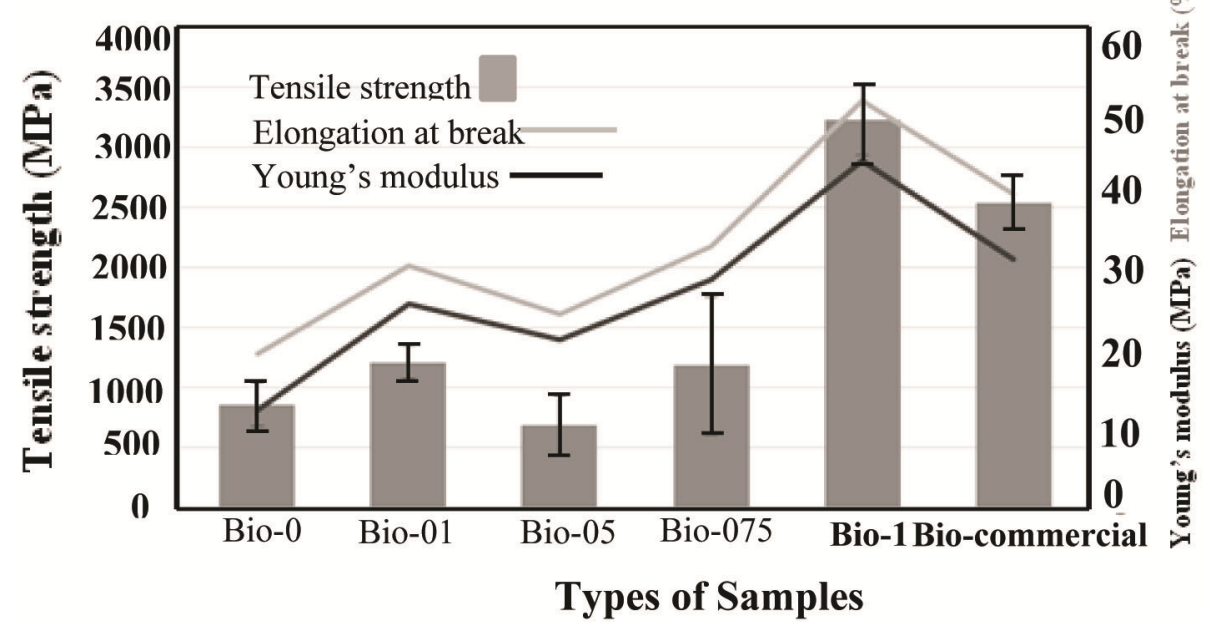

Figure 10. Mechanical properties of biocellulose tissue engineering and bio-commercial facial masks

\section{Conclusion}

The obtained results of the preparation of biocellulose nanocomposite fiber with added eggshell membrane powder indicate their potential to produce biocellulose tissue engineering or facial masks. There are many advantages such as biocompatibility, ease formation, good physicochemical and mechanical properties, nontoxic, elasticity, transparency, good ability to adsorption water, vitamin $\mathrm{C}$ and vitamin $\mathrm{E}$ as hydrogel-like and ability to adsorb oil. The best samples were using Bio-1which had high tensile strength $(3.229 \pm 0.297 \mathrm{MPa})$, elongation at break $(43.350 \pm 8.400 \%)$ and good maximum force $(13.466 \pm 1.238 \mathrm{~N})$ compared to those of the bio-commercial facial masks. Furthermore, the results of the current study can be applied to various applications in advanced biomaterial products such as wound healing and dressing, regenerative tissues, periodontal treatments, tissue engineering for bone, cartilage, blood vessel engineering and skin tissue repair.

\section{Acknowledgements}

The authors sincerely thank the Department of Materials Engineering, at Kasetsart University, Bangkok, Thailand and the Thailand Scientific and Technological Research Equipment Center, at Chulalongkorn University, Bangkok for the use of analytical instruments. We also thank the Energy and Environmental Engineering Center, Faculty of Engineering, Kasetsart University for the eggshell separation. This work was supported by a grant from the Agricultural Research Development Agency (Public Organization) or ARDA of the Ministry of Agriculture and Cooperatives, the Thailand Research Fund (TRF), and the Royal Thai Government for targeting research on herbs, supplementary foods.

\section{Conflict of Interest}

The authors declare there are no commercial or associative interests that represent a conflict of interest in connection with the work submitted.

\section{References}

Aramwit P, Bang N. (2014). The characteristics of bacterial nanocellulose gel releasing silk sericin for facial treatment. BMC Biotechnol, 14(104), 1-11. https://doi.org/10.1186/s12896-014-0104-x

Barud HS, Rigiani T, Marques RF, Lustri WR, Messaddeq Y, Ribeiro SJ. (2011). Antimicrobial bacterial cellulose-silver nanoparticles composite membranes. J. Nanomater, 1-8. https://doi.org/10.1155/2011/721631

Butchosa N, Brown C, Larsson PT, Berglund LA, Bulone V, Zhou Q. (2013). Nanocomposites of bacterial cellulose nanofibers and chitin nanocrystals: fabrication, characterization and bactericidal activity. Green Chem., 15(12), 3404-3413. https://doi.org/10.1039/c3gc41700j

Cacicedo ML, Castro MC, Servetas I, Bosnea L, Boura K, Tsafrakidou P, et al. (2016). Progress in bacterial cellulose matrices for biotechnological applications. Bioresour. Technol, 213, 172-180. https://doi.org/10.1016/j.biortech.2016.02.071

Czaja W, Krystynowicz A, Bielecki S, Brown RM. (2006). Microbial cellulose--the natural power to heal wounds. Biomaterials, 27(2), 145-151. https://doi.org/10.1016/j.biomaterials.2005.07.035 
Dobre LM, Stoica-Guzun A, Stroescu M, Jipa I, Dobre T, Ferdeş M. (2012). Modeling of sorbic acid diffusion through bacterial cellulose-based antimicrobial films. Chem. Pap. 66(2), 144-151. https://doi.org/10.2478/s11696-011-0086-2

Fu L, Zhang J, Yang G. (2013). Present status and applications of bacterial cellulose-based materials for skin tissue repair. Carbohydr. Polym., 92, 1432-1442. https://doi.org/10.1016/j.carbpol.2012.10.071

Grande CJ, Torres FG, Gomez CM, Baňŏ MC. (2009). Nanocomposites of bacterial cellulose/hydroxyapatite for biomedical applications. Acta Biomater, 5(5), 1605-1615. https://doi.org/10.1016/ j.actbio.2009.01.022

Hasan N, Biak DRA, Kamarudin S. (2012). Application of bacterial cellulose (BC) in natural facial scrub. Int. J. Adv. Sci. Eng. Inf. Technol., 2(4), 1-4. https://doi.org/10.18517/ijaseit.2.4.201

$\mathrm{Hu}$ W, Chen S, Yang J, Li Z, Wang H. (2014). Functionalized bacterial cellulose derivatives and nanocomposites. Carbohydr. Polym., 101, 1043-1060. https://doi.org/10.1016/j.carbpol.2013.09.102

Iguchi M, Yamanaka S, Budhiono A. (2000). Bacterial cellulose-a masterpiece of nature's arts. J.Mater Sci., 35, 261-270 (2000). https://doi.org/10.1023/A:1004775229149

Jang WD, Hwang JH, Kim HUK, Ryu JY, Lee SY. (2017). Bacterial cellulose as an example product for sustainable production and consumption. Microb. Biotechnol, 10, 1181-1185. https://doi.org/10.1111/1751-7915.12744

Jiang F, Yin L, Yu Q, Zhong C, Zhang J. (2015). Bacterial cellulose nanofibrous membrane as thermal stable separator for lithium-ion batteries. J. Power Sources., 279, 21-27. https://doi.org/10.1111/1751-7915.12744

King'ori AM. (2011). A Review of Uses of Poultry Eggshells and Shell Membranes. Int.J. Poul. Sci., 10(11), 908-912 (2011). https://doi.org/10.3923/ijps.2011.908.912

Legnani C, Vilani C, Calil V, Barud H, Quirino W, Achete C et al. (2008). Bacterial cellulose membrane as flexible substrate for organic light emitting devices. Thin Solid Films, 517, 1016-1020. https://doi.org/10.1016/j.tsf.2008.06.011

Li Z, Wang L, Hua J, Jia S, Zhang J, Liu H. (2015). Production of nano bacterial cellulose from waste water of candied jujube-processing industry using Acetobacter xylinum. Carbohydr. Polym., 120, 115-119. https://doi.org/10.1016/j.carbpol.2014.11.061

Matsuda N, Koyama Y, Hosaka Y, Ueda H, Watanabe T, Araya T, Irie S, Takehana K. (2006). Effect of Ingestion of Collagen Peptide on collagen Fibrils and Glycosaminoglycans in the Dermis. J. Nutr. Sci. Vitaminol, 52, 211-215. https://doi.org/10.3177/jnsv.52.211

Mogoşanu GD, Grumezescu AM. (2014). Natural and synthetic polymers for wounds and burns dressing. Int. J. Phamaceut, 463, 127-136. https://doi.org/10.1016/j.ijpharm.2013.12.015

Ruff KJ, Morrison D, Duncan SA, Back M, Aydogan C, Theodosakis J. (2018). Beneficial effects of natural eggshell membrane versus placebo in exercise-induced joint pain, stiffness, and cartilage turnover in healthy, postmenopausal women. Clin. Interv.Aging., $13, \quad 285-295 \quad$ (2018). https://doi.org/10.2147/CIA.S153782

Tangboriboon N, Pornsimma S, Sirivat A. (2016). Embedding Eggshell as Flux in Porcelain Clay Products to Reduce Firing Temperature via Extrusion Process. Middle-East J. Sci. Res., 24(5), 1616-1621. https://doi.org/10.5829/idosi.mejsr.2016.24.05.23462

Tomita Y, Kondo T. (2009). Influential factors to enhance the moving rate of Acetobacter xylinum due to its nanofiber secretion on oriented templates. Carbohydr. Polym., 27, 754-759. https://doi.org/10.1016/ j.carbpol.2009.02.022

Torres FG, Troncoso OP, Piaggio F, Hijar A. (2010). Structure-property relationships of a biopolymer network: The eggshell membrane. Acta Biomater, 6, 3687-3693. https://doi.org/10.1016/j.actbio.2010.03.014.

Tsai WT, Yang JM, Lai CW, Cheng YH, Lin CC, Yeh Cw. (2006). Characterization and adsorption properties of eggshells and eggshell membrane. Bioresour. Technol, 97, 488-493. https://doi.org/10.1016/j.biortech.2005.02.050

UI-Islam M, Khan T, Khattak WA, Park JK. (2013). Bacterial cellulose-MMTs nanoreinforced composite films: novel wound dressing material with antibacterial properties. Cellulose, 20(2), 589-596. https://doi.org/10.1007/s10570-012-9849-3 
Ullah H, Santos HA, Khan T. (2016). Applications of bacterial cellulose in food, cosmetics and drug delivery. Cellulose, 23, 2291-2314. https://doi.org/10.1007/s10570-016-0986-y

Ummartyotin S, Pechyen C. (2016). Strategies for development and implementation of bio-based materials as effective renewable resources of energy: A comprehensive review on adsorbent technology. Renew. Sus. Energ. Rev., 62, 654-664. https://doi.org/10.1016/j.rser.2016.04.066

Upadhyay A, Lama JP, Tawata S. (2010). Utilization of Pineapple Waste: A Review. J. Food Sci. Technol. Nepal, 6, 10-18. https://doi.org/10.3126/jfstn.v6i0.8255

Verschuren PG, Cardona TD, Robert Nout MJ, Gooijer KD, Den Huevel JV. (1999). Location and limitation of cellulose productin by acetobacter xylinum established from oxygen profiles. J. Biosci. Bioeng, 89(5), 416-419. https://doi.org/10.1016/S1389-1723(00)89089-1

Yano H, Sugiyama J, Nakagaito AN, Nogi M, Matsuura T, Hikita M, et al. (2005). Optically transparent composites reinforced with networks of bacterial nanofibers. Adv. Mater., 17(2), 153-155. https://doi.org/10.1002/adma.200400597

Yi F, Guo ZX, Zhang LX, Yu J, Li Q. (2004). Soluble eggshell membrane protein: preparation, characterization and biocompatibility. Biomaterials, 25, 4591-4599. https://doi.org/10.1016/j.biomaterials.2003.11.052

\section{Copyrights}

Copyright for this article is retained by the author(s), with first publication rights granted to the journal.

This is an open-access article distributed under the terms and conditions of the Creative Commons Attribution license (http://creativecommons.org/licenses/by/4.0/). 